\title{
Phylogenetic analysis of dematiaceous fungi isolated from the soil of Guangdong, China
}

\author{
Xiaoyan $\mathrm{Hu}^{1^{\star}}$, Liyan $\mathrm{Xi}^{2}$, Hongyun $\mathrm{Lu}^{3}$, Jiawang Feng ${ }^{4}$, Sa $\mathrm{Lu}^{2}$, Changing $\mathrm{Lu}^{2}$ and Jiufeng Sun ${ }^{2}$ \\ ${ }^{1}$ Department of Dermatology, The Fifth Affiliated Hospital, Sun Yat-Sen University, Guangdong, Zhuhai 519000, China. \\ ${ }^{2}$ Department of Dermatology, The Second Affiliated Hospital, Sun Yat-Sen University, Guangdong, \\ Guangzhou 510120, China. \\ ${ }^{3}$ Department of Endocrinology, The Fifth Affiliated Hospital, Sun Yat-sen University, Guangdong, Zhuhai 519000, China. \\ ${ }^{4}$ Zhuhai Entry-Exit Inspection and Quarantine Bureau of PRC, Guangdong, Zhuhai 519015, China.
}

Accepted 23 August, 2011

\begin{abstract}
To search for the dematiaceous fungi in nature, clarify their habitat and the environmental circumstances in which they may infect man, we studied the phylogenetic relationships of these isolates. 60 dematiaceous fungal strains out of 367 soil samples were isolated. They were further identified by molecular biological method. The phylogenetic relationships were demonstrated by using internal transcribed spacer (ITS) region of ribosomal DNA sequences. In the neighbor-joining (NJ) tree, Phialophora sp., Cladophialophora chaetospira, Exophiala spinifera, Phaeococcomyces sp. and Exophiala eucalyptorum formed cluster A, Didymella bryoniae, Leptosphaeriaceae sp., Ascomycete sp., Microdiplodia hawaiiensis and Cochliobolus lunatus formed cluster B, Staninwardia suttonii, Cladosporium oxysporum, Cladosporium cladosporioides, Cladosporium sp. and Melanized limestone ascomycete formed cluster C, and Scolecobasidium tereum, Scolecobasidium humicola formed cluster D. The phylogenetic relationships between cluster B, cluster $\mathbf{C}$ and cluster $\mathbf{D}$ were closer than that of cluster A. Dematiaceous species were found widely in Guangdong soil, and the distribution amounts were not in a specific pattern, the phylogenetic method based on the rDNA ITS sequence was proven to be a quick and accurate fungi identify method. There is a relationship between genetic distances and some biological habits of some strains, but lacking of connection was found between the genetic distances and the geographical factors.
\end{abstract}

Key words: Dematiaceous fungi, isolation, phylogenetic tree, internal transcribed spacer (ITS) region, ribosomal DNA (rDNA).

\section{INTRODUCTION}

With the increasing of invasive fungal infection (Marr et al., 2002; Pfaller and Diekema, 2004; Trick et al., 2002; Wisplinghoff et al., 2004; Baddley et al., 2001) emerging pathogens have been increasingly recognized as important pathogens. We face a marked shift in the epidemiological profile of fungal infections: new and emerging pathogens including some dematiaceous fungi (e.g. Alternaria sp., Bipolaris spp, Curvularia spp., Cladophialophora spp., Exophiala spp., Phialophora) are

${ }^{\star}$ Corresponding author. E-mail: xiaoyanhu5@yahoo.com.cn. Tel: +86-756-2528745. Fax: +86-756-2528210. increasingly being reported (Malani and Kauffman, 2007; Richardson and Lass-Flörl, 2008). Because risk-factors for these infections continue to increase in frequency, it is likely that the incidence of the emerging pathogens infections will continue to increase in the coming decades.

Dematiaceous or darkly pigmented fungi are uncommon causes of human disease but can be responsible for life-threatening infections in both immunocompromised and immunocompetent individuals (Revankar and Sutton, 2010; Schell, 1995). They are a heterogeneous group. The distinguishing characteristic common to all these various species is the presence of melanin in their cell walls, which imparts dark color to their conidia or spores 
Table 1. Localities, sites and number of soil samples collected in Guangdong, PR china.

\begin{tabular}{|c|c|c|c|c|c|c|}
\hline \multicolumn{7}{|c|}{ Localities } \\
\hline \multirow{2}{*}{ Site } & \multirow{2}{*}{ North * } & \multicolumn{3}{|c|}{ Medio - region $†$} & \multirow{2}{*}{ South $\ddagger$} & \multirow{2}{*}{ Tota } \\
\hline & & Eastern§ & Central ף & Western \# & & \\
\hline Field & 14 & 64 & 79 & 32 & 42 & 231 \\
\hline Forest & 4 & 9 & 17 & 2 & 3 & 35 \\
\hline Farm & 2 & 1 & 11 & & & 14 \\
\hline Waterside & & 3 & 9 & 5 & 5 & 22 \\
\hline Road side & 5 & 6 & 4 & 14 & 2 & 31 \\
\hline Factory & & 4 & 9 & & & 13 \\
\hline Others & 1 & 7 & 9 & 2 & & 19 \\
\hline Total & 26 & 94 & 138 & 55 & 52 & 365 \\
\hline
\end{tabular}

*: indicates the north region of Guangdong with the medio-subtropical region; $\dagger$ : the middle region of Guangdong with the south subtropical region; $\ddagger$ : the south region of Guangdong with the north tropical region; §: the east of the middle region of Guangdong; ף: the middle region of Guangdong; \#: the west of the middle region of Guangdong. The west of the middle region of Guangdong with the south subtropical region is Zhaoqing Gaoyao West; the central of the middle region of Guangdong with the south subtropical region is Zhaoqing Gaoyao East to Heyuan; the east of the middle region of Guangdong with the south subtropical region is Heyuan East.

and hyphae. The colonies are typically brown to black in color as well. Dematiaceous fungi are commonly found in the soil and generally distributed worldwide (Montenegro et al., 1996; Dixon et al., 1980; Lopez et al., 2004). They are the etiologic agents of phaeohyphomycosis, chromoblastomycosis and mycetima. Over 100 species and 60 genera of dematiaceous fungi have been implicated in human disease (Matsumoto et al., 1994).

As these diseases usually occur by the penetration of the causative agent through skin wounds, it is significant to search for the agents in nature, clarify their habitat and the environmental circumstances in which they may infect man. Agents (Dixon et al., 1980; Yegres et al., 1991) have been isolated such as Phialophora spp., Cladosporium spp., Exophiala spp., Sporothrix sp., Wangiella dermatitdis, Bispora betulina, and Scytalidium lignicola, which demonstrated the presence of pathogenic dematiaceous fungi in nature, although the identity of most of these strains has not been verified by molecular data. Nishimura (Nishimura, 1994) and Nishimura et al. (Nishimura et al.1989) investigated the ecology of pathogenic fungi in natural and living environments in Colombia, Venezuela, Brazil, China and Japan and succeeded in isolating various species of pathogenic dematiaceous fungi including Fonsecaea pedrosoi, Phialophora verrucosa and Exophiala spinifera. They did not find the fungus Cladophialophora spp., which are the mainly causative agents of chromoblastomycosis in China.

The taxonomy and identification of dematiaceous fungi are difficult due to a lack of phenetic characters and high degree of morphological plasticity. In the present study, we isolated 60 dematiaceous fungal strains out of 367 soil samples; these were further identified by molecular biological method. If the phylogenetic relationship and the geographical distribution of dematiaceous fungi from soil of Quangdong, PR china, are revealed, it will be useful for future study.

\section{MATERIALS AND METHODS}

\section{Sample collection}

There are three climatic zones in Guangdong: the central subtropical (Nanxiong, Lianshan, Lianxian and Shaoguan), the sourthern subtropical (Yingde, Meixian, Shantou, Guangzhou, Yangjiang), and the northern tropical (Zhanjiang, Xuwen). 365 samples were collected from the three climatic zones where four to ten collecting sites were set up randomly (Table 1). The work was done during autumn and winter (October 2006 to January 2007), the dry season in Guangdong. Samples were collected from the surface soil upward of $15 \mathrm{~cm}$. Utilizing a spoon which was rinsed with sterile water after each use, approximately $25 \mathrm{~g}$ sample were placed in $100 \mathrm{ml}$ plastic bottles containing a small crystal of paradichlorobenzene (for arthropod control), and returned to the laboratory for processing on the same day.

\section{Isolation of dematiaceous}

$3 \mathrm{~g}$ of soil were transferred to a sterile $15 \mathrm{ml}$ glass tube; $10 \mathrm{ml}$ of sterile saline were then added, mixed by agitation for $1 \mathrm{~min}$ and set for $20 \mathrm{~min}$, after which it was diluted to the concentration of the proportion of $1: 100$, when $0.2 \mathrm{ml}$ was collected from the middle part of the soil suspension and placed on two plates. Then, the solution was poured on two media; potato dextrose agar (PDA) Rose Bengal respectively, both containing antibiotics $(50 \mathrm{mg}$ of chloramphenicol, $10^{6}$ units of penicillin, $200 \mathrm{mg}$ of streptomycin and $200 \mathrm{mg}$ of cyclohexamide per liter). Pulled a medium to 3 plates, sealed the plates with plastic film, left a hole of 3 to $5 \mathrm{~mm}$. The plates were incubated at $26^{\circ} \mathrm{C}$ for 2 to 3 weeks. The suspected colonies were subculture on Sabouraud dextrose agar (SDA) at $25^{\circ} \mathrm{C}$ and cheeked grossly and microscopically. All isolates were further evaluated by molecular biology methods.

\section{DNA extraction, PCR amplification}

DNA was extracted using $6 \%$ In Sta Gene TM Matrix (BioRad, 
Table 2. List of reference sequences.

\begin{tabular}{lll}
\hline GenBankaccession & Name & Geography \\
\hline EU035406.1 & C. chaetospira & Germany \\
AB456580.1 & E. spinifera & Japan: Osaka \\
AB456578.1 & P. europaea & Japan: Osaka \\
AJ972801.1 & Phaeococcomyces sp. & Turkey: Mediterranean \\
DQ092530.1 & Leptosphaeriaceae sp. & USA: Kuli'ou'ou Beach Park in Hawaii Kai, Oahu, Hawaii \\
AF297228.1 & D. bryoniae & USA \\
DQ923535.1 & S. suttonii & Australia \\
EU272531.1 & C. tenuissimum & Colombia: Andean paramo ecosystem \\
EU714392.1 & Scolecobasidium sp. & Thailand: southern Thailand, Gulf of Thailand and Andaman Sea \\
\hline
\end{tabular}

U.S.A.). rDNA ITS domains (including part of 18S, ITS I ,5S, ITS II, part of 26S ) were amplified in a Biometra T-Gradent Thermoblock (Germany) using primers ITS-4 (5'-TCCTCCGCTTATTGATATGC-3') and ITS-5 (5'-GGAAGTAAAAGTCGTAACAAGG-3'), which were described previously (Abliz et al., 2004). Each PCR mixture contained $5 \mu \mathrm{l}$ of $10 \times$ reaction buffer (Pharmacia), $4 \mu \mathrm{l} 10 \times \mathrm{dNTP}$, $0.2 \mathrm{U}$ Taq polymerase, $1 \mu \mathrm{l}$ primer, and $2 \mu \mathrm{l}$ DNA template solution. Ultrapure water was added to increase the volume to $50 \mu \mathrm{l}$. Each reaction mixture was heated to $95^{\circ} \mathrm{C}$ for $4 \mathrm{~min}$, followed by 30 cycles of $94^{\circ} \mathrm{C}$ for $30 \mathrm{~s}, 55^{\circ} \mathrm{C}$ for $30 \mathrm{~s}$, and $72^{\circ} \mathrm{C}$ for $60 \mathrm{~s}$., followed by incubation for $10 \mathrm{~min}$ at $72^{\circ} \mathrm{C}$.

\section{Direct sequencing and phylogenetic analysis}

Direct sequencing of PCR products was done with an $A B I P R I S M$ 3100 sequencer ( $\mathrm{BBI}$, America) after labeling with BigDye Terminator Cycle Sequencing Ready Reaction (Applied Biosystems, Foster City, California). The ITS sequences of reference sequence from GenBank collection (Table 2) and isolated dematiaceous fungal (Table 3 ) in this study were aligned by using Clustal W software. Phylogenetic tree was then constructed by the neighborjoining (NJ) method in the Molecular Evolutionary Genetics Analysis (MEGA) software version 4.0 (Tamura, 2007). Bootstrap analysis with the MEGA program was performed by taking 500 random samples from the multiple alignments (values $>50$ are shown with the branches). The evolutionary distance between organisms is indicated by the horizontal branch length, which reflects the number of nucleotide substitutions per site along that branch from node to the endpoint.

\section{RESULTS}

Within 367 soil samples, 15 genera, 33 species and 60 dematiaceous fungal strains (including 14 pathogenic dematiaceous fungal strains) were isolated. All isolates (Table 3) were identified by molecular biological method. The rDNA ITS regions (including part of 18S, ITS I , 5S, ITS II , part of 26S) were successfully amplified from all the dematicacious fungi by universal primers. The size of acquired PCR products ranged from $500 \mathrm{bp}$ to $650 \mathrm{bp}$. Each strain of dematicacious fungi tested was shown to have unique ITS base sequences, although some of them were very similar.

In the phylogenetic tree (Figure 1) constructed from data of 60 strains and 9 reference strains, Phialophora sp., Cladophialophora Chaetospira, E. spinifera, Phaeococcomyces sp. and Exophiala eucalyptorum formed cluster A, Didymella bryoniae, Leptosphaeriaceae sp., Ascomycete sp., Microdiplodia hawaiiensis and Cochliobolus lunatus formed cluster B, Staninwardia suttonii, Cladosporium oxysporum, Cladosporium cladosporioides, Cladosporium sp. and Melanized limestone ascomycete formed cluster $\mathrm{C}$, and Scolecobasidium tereum, Scolecobasidium humicola formed cluster D. Obviously, the phylogenetic relationships between cluster A, cluster B and cluster C were more closer than that of cluster $\mathrm{D}$.

\section{DISCUSSION}

Studies of an infectious disease usually approach from pathogens, so isolations and identificatons of pathogens are the most important parts in the approach. The usual identification of fungi by the morphological method, combining with some biochemical approaches, processes the observation of colonial textures, shapes, and colors in culture mediums, and the inspection of conidiophores, morphologies and generations of conidia. However, it is difficult because many dematicacious fungi appear in multi-morphologies, which the isolate may generate more than one kind of conidium or may be generated by various conditions. Therefore, it is not easy to determine whether a conidium is yielded by the multi-morphological fungi or by a mixture of fungi. To obtain an isolate with high purity, it requires sub-cultures from the similar culture medium. Even with the required conditions of subculture, some colonies are complicated to isolate. Furthermore the members of mitosporic fungi are taxonomically closely related, morphological identification of mitosporic fungi becomes more difficult. Early studies have shown that the results from the molecular biological identification of fungi are in accordance with of the morphology identification (Pechere et al., 1999). In this study, a series of colony complexes are involved. We identified all the strains by the molecular biological method and processed the morphology method to classify some isolates. 
Table 3. List of strains isolated and source.

\begin{tabular}{|c|c|c|}
\hline Strain name & Source & Climate zone \\
\hline E. pisciphila & The bamboo grove & Medio-subtropical \\
\hline E. eucalyptorum & The grassland & Western of south subtropical \\
\hline E. xenobiotica & The drainage & Middle of south subtropical \\
\hline E. oligosperma & The stream & Eastern of south subtropical \\
\hline E. mesophila & The rice field & Eastern of south subtropical \\
\hline Exophiala sp. & The roadside & Eastern of south subtropical \\
\hline E. dermatitidis & The sideway & Western of south subtropical \\
\hline Phaeococcomyces sp. & The roadside & Western of south subtropical \\
\hline Phaeococcomyces sp. & The roadside & Western of south subtropical \\
\hline Phaeococcomyces sp. & The hillside & Western of south subtropical \\
\hline Phaeococcomyces sp. & The root of tree & Eastern of south subtropical \\
\hline Phaeococcomyces sp. & The taro field & North-tropical \\
\hline Phialophora sp. & The rice field & Western of south subtropical \\
\hline Phialophora sp. & The rice field & Western of south subtropical \\
\hline C. chaetospira & The bamboo grove & Medio-subtropical \\
\hline C. chaetospira & The taro field & Medio-subtropical \\
\hline C. carrionii & The root of tree & Medio-subtropical \\
\hline C. chaetospira & The factory zone & Middle of south subtropical \\
\hline C. chaetospira & The hill & Eastern of south subtropical \\
\hline C. devriesii. & The rice field & Eastern of south subtropical \\
\hline C. chaetospira & The nursery & North-tropical \\
\hline C. chaetospira & The sweet potato field & North-tropical \\
\hline C. chaetospira & The roadside & Middle of south subtropical \\
\hline C. chaetospira & The hillside & Western of south subtropical \\
\hline C. oxysporum & The vegetable field & Middle of south subtropical \\
\hline C. cldosporioides & The drainage & Middle of south subtropical \\
\hline Cladosporium sp. & The vegetable field & Eastern of south subtropical \\
\hline C. cladosporioides & The farmland & Eastern of south subtropical \\
\hline C. oxysporum & The pinking field & North-tropical \\
\hline C. oxysporum & The sweet potato field & North-tropical \\
\hline C. oxysporum & The cucumber field & North-tropical \\
\hline S. tereum & The pigsties & Medio-subtropical \\
\hline S. tereum & The pineapple field & Western of south subtropical \\
\hline S. tereum & The roadside & Western of south subtropical \\
\hline S. tereum & The rice field & Western of south subtropical \\
\hline S. tereum & The rice field & Medio-subtropical \\
\hline S. tereum & The vegetable field & Middle of south subtropical \\
\hline S. tereum & The crown field & Middle of south subtropical \\
\hline S. tereum & The grassland & Middle of south subtropical \\
\hline S. tereum & The drainage & Middle of south subtropical \\
\hline S. tereum & The onion field & Middle of south subtropical \\
\hline S. tereum & The Chinese eggplant field & Middle of south subtropical \\
\hline S. humicola & The papaya field & Eastern of south subtropical \\
\hline S. humicola & The chicken shed & Eastern of south subtropical \\
\hline S. tereum & The grass land & Eastern of south subtropical \\
\hline S. tereum & The vegetable field & Eastern of south subtropical \\
\hline S. tereum & The vegetable field & Eastern of south subtropical \\
\hline S. tereum & The vegetable field & Eastern of south subtropical \\
\hline S. suttonii & The grassland & Western of south subtropical \\
\hline S. suttonii & The roadside & Middle of south subtropical \\
\hline D. bryoniae & The orchard & Western of south subtropical \\
\hline
\end{tabular}


Table 3. Contd.

\begin{tabular}{lll}
\hline Capnoclium sp. & The duck shed & Middle of south subtropical \\
M. limestone ascomycete & The factory zone & Middle of south subtropical \\
Leptosphaeriaceae sp. & The vegetable field & Middle of south subtropical \\
Leptosphaeriaceae sp. & The grassland & Eastern of south subtropical \\
Ascomycete sp. & The root of tree & Middle of south subtropical \\
Ascomycete sp. & The banana field & Middle of south subtropical \\
M. Alistairii & The rice field & North-tropical \\
C. lunatus & The Chinese potato field & Eastern of south subtropical \\
M. hawaiiensis & The drainage & Middle of south subtropical \\
\hline
\end{tabular}

Results indicated that dematiaceous species were found widely in Guangdong soil. However, the distribution amounts were not in a pattern. Defined by climatic zones, the western species of the southern subtropical are with the highest abundance and density; the eastern species of the southern subtropical are with the lowest abundance and density. The most found genus was Scolecobasidium. There were 17 samples found and it was $28 \%(17 / 60)$ of the positive results. There is no detailed report found on its pathogenicity. Ten strains of Cladophialophora were found from 10 samples, which was $17 \%(10 / 60)$ of the positive results. Among them, the isolates of Cladophialophora carrionii were from the garden of Yuanshan Qingyuan. It has been the first time that $C$. carrionii which is the common pathogen for chromoblastomycosis in China was isolated from samples of Guangdong environment. Seven strains of Exophiala were recognized, including $E$. dermatitidis, $E$. xenobiotica, E. oligosperma, E. pisciphila, E. mesophila, Exophiala sp., E. eucalyptorum. Except E. eucalyptorum, the rest strains were common pathogens. Phaeococcomyces is a member of black yeast, which is hard to identify because its confusion on the morphology. Five strains were found from the experiment, but the species was not determined. Two isolates of Phialophora parasitica were found. There are 25 members in Phialophora of which five species are human pathogens, including $P$. verrucosa, $P$. richardsiae, $P$. repens, $P$. parasitica, and $P$. cyanescens (Park et al., 2005). The common pathogen $P$. verrucosa of chromoblastomycosis was not found in this experiment which may be because it intends to distribute in the cold zone (Liu et al., 2004). Cladosporium, dispensing widely, is the saprophyte found usually in soil and on plants, and is also the pathogen for plants. Some of Cladosporium are relative to human infections (Chew et al., 2009; Gugnani et al., 2006). Seven strains were found in this experiment, including four strains of $C$. oxysporum, two strains of $C$. cldosporioides, and one strain of $C$. sphaerospermum. The three species can cause human phaeohyphomycosis. C. oxysporum presents in the warm condition (Mckemy and Morgan, 1991). It is compliant with the four strains that have been from farms of Zhuhai and
Zhanjiang Leizhou. The locations are warmer than the Chinese lettuce field in Meizhou from which the mould of the $C$. sphaerospermum strain is Meizhou is in the further northern region. One strain of $D$. bryoniae, plant pathogen, was isolated. Some studies have shown the fungi of Didymella are related to asthma (Pulimood et al., 2007), because the amount of the fungi increases during the storm season, which may lead to asthma.

There is no human disease reported for the rest eleven findings, including two strains of $S$. suttonii, one strain of Capnoclium sp., one strain of Melanized limestone ascomycete, two strains of Leptosphaeriaceae sp., two strains of Ascomycete sp., one strain of Mycosphaerella Alistairii, one strain of C. lunatus, one strain of Microdiplodia hawaiiensis. The major pathogen Fonsecaea pedrosoi of chromoblastomycosis was not found in the experiment. Are the substances foci suitable for Fonsecaea pedrosoi growing not the soil but other material, such as plant, litter and wheat stalk? May the condition factors of the experiment, such as culture medium, temperature or other involved fungi also play the role to inhibit the species survive? Further studies will be needed to address the above questions.

Using rDNA ITS sequences from 60 newly isolated strains and 9 reference strains, we constructed phylogenetic tree of dematicacious fungi. The phylogenetic method based on the ITS rDNA sequence to identify fungi agreed with the morphological method, even if more quick and accurate. The NJ tree indicates the relationships between genetic distances and some biological habits of strains, for example, the strains that can cause diseases in human and animal often group together (Cladophialophora carrionii, Cladophialophora devriesii, Cladophialophora oxysporum, Cladophia-lophora cldosporioides, E. dermatitidis, E. xenobiotica, E. oligosperma, E. pisciphila, E. mesophila, D. bryoniae), on the other hand, the strains that can cause diseases in plants usually get into other crowd. There is no evidence showing that the sorting relates to the geographical location, while the same kind strains from different regions reveal similar genetic distances. Therefore, the strains within the crowd or with closer genetic distance would be also with potential pathogenicity. Development 


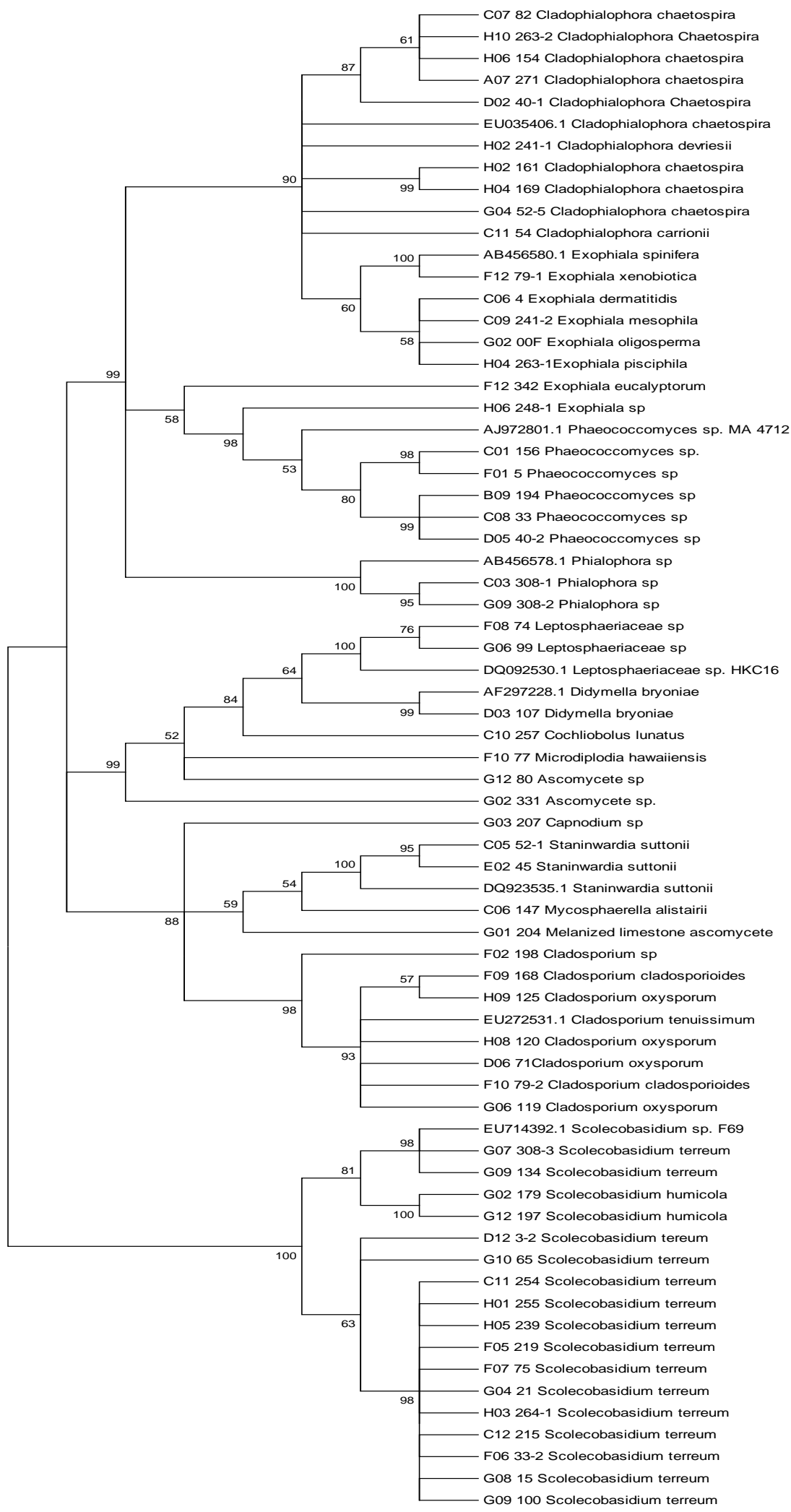

Figure 1. Phylogenetic tree constructed by neighbor-joining $(\mathrm{NJ})$ method. The tree was constructed using 500 bootstrap replications (values $>50$ are shown with the branches). The evolutionary distance between organisms is indicated by the horizontal branch length, which reflects the number of nucleotide substitutions per site along that branch from node to the endpoint. 
of $\mathrm{NJ}$ tree would not only effect on identifications of fungal strains but would also play a role on guiding the studies on some biological habits of the strains.

\section{ACKNOWLEDGEMENTS}

This work was supported by the Social development projects of Science and Technology Commission of Guangdong Province (83004). The authors would like to thank all the people who gave help to the present study for soil sample collection. Thanks also go to Dr. Baozheng Luo, Ying Li of Zhuhai Entry-Exit Inspection and Quarantine Bureau of PRC for their technical assistance in the laboratory and editorial assistance.

\section{REFERENCES}

Abliz P, Fukushima K, Takizawa K, Nishimura K (2004). Specific Oligonucleotide Primers for Identification of Cladophialophor acarrionii, a Causative Agent of Chromoblastomycosis. J. Clin. Microbiol., 42(1): 404-407.

Baddley JW, Stroud TP, Salzman D, Pappas PG (2001). Invasive mold infections in allogeneic bone marrow transplant recipients. Clin. Infect. Dis., 32: 1319-1324.

Chew FL, Subrayan V, Chong PP, Goh MC, Ng KP (2009). Cladosporium cladosporioides keratomycosis: a case report. Jpn. J. Ophthalmol., 53: 657-659.

Dixon DM, Shadomy HJ, Shadomy S (1980). Dematiaceous fungal pathogens isolated from nature. Mycopathologia, 70: 153-161.

Gugnani HC, Ramesh V, Sood N, Guarro J, Moin-Ul-Haq, Paliwal-Joshi A, Singh B (2006). Cutaneous phaeohypho-mycosis caused by Cladosporium oxysporum and its treatment with potassium iodide. Med. Mycol., 44: 285-288.

Liu H, Kauffman S, Becker JM, Szaniszlo PJ (2004). Wangiella (exophiala) dermatitidis WdChs5p, a class $\mathrm{V}$ chitin synthase, is essential for sustained cell growth at temperature of infection. Eukaryot Cell, 3: 40-51.

Lopez AI, Gonzalez AE, Teron MC (2004). Ecological study of the fungal populations of the acidic Tinto Rive in southwestern Spain. Can. J. Microbiol., 50: 923-934.

Malani AN, Kauffman CA (2007). Changing epidemiology of rare mould infections: implications for therapy. Drugs, 67: 1803-1812.

Marr AK, Carter R, Crippa F, Wald A , Corey L (2002). Epidemiology and outcome of mould infections in hematopoietic stem cell transplant recipients. Clin. Infect. Dis., 34: 909-917.

Matsumoto T, Ajello L, Mastuda T, Szaniszlo PJ, Walsh TJ (1994). Developments in hyalohyphomycosis and phaeohyphomycosis. J. Med. Vet. Mycol., 32: 329-349.
Mckemy JM, Morgan-Jones G (1991). Studies in the genus Cladosporium sensu lato IV Concerning Cladosporium oxysporum a pleurivorous, Predominantly saprophytic species in warm climates. Mycotaxon, 50: 397-405.

Montenegro MR, Miyaji M, Franco M, Nishimura K, Coelho KI, Horie Y, Mendes RP, Sano A, Fukushima K, Fecchio D (1996). Isolation of fungi from nature in the region of Botucatu, state of São Paulo, Brazil, an endemic area of Paracoccidioidomycosis. Mem Inst Oswaldo Cruz 91: 665-670.

Nishimura K (1994). The ecology of pathogenic dematiaceous fungi. Jpn. J. Med. Mycol., 35: 385-391.

Nishimura K, Miyaji M, Taguchi H, Wang DL, Li RY, Meng ZH (1989). An ecological study of dematiaceous fungi in China. Proceedings of the $4^{\text {th }}$ International Symposium of the Research Center for Pathogenic Fungi and Microbial Toxicoses, Chiba University, Chiba. pp. 17-20.

Park GS, Oh SH, Suh SB, Lee KH, Chung KY (2005). A case of chromoblastomycosis with an unusual manifestation caused by Phialophora verrucosa on an unexposed area:treatment with a combination of amphotericin B and 5-flucytosine. Br. J. Dermatol., 152: $560-564$.

Pechere M, Krischer J, Remondat C, Bertrand C, Trellu L, Saurat JH (1999). Malassezia spp carriage in patients with seborrheic dermatitis. J. Dermatol., 26: 558-561.

Pfaller MA, Diekema DJ (2004). Rare and emerging opportunistic fungal pathogens: concern for resistance beyond Candida albicans and Aspergillus fumigatus. J. Clin. Microbiol., 42: 4419-4431.

Pulimood TB, Corden JM, Bryden C, Sharpkes L, Nasser SM (2007). Epidemic asthma and the role of the fungal mold Alternaria alternate. J. Allergy Clin. Immunol., 120: 610-617.

Revankar SG, Sutton DA (2010). Melanized Fungi in human disease. Clin. Microbiol. Rev., 23: 884-928.

Richardson M, Lass-Flörl C (2008). Changing epidemiology of systemic fungal infections. Clin. Microbiol. Infect., 14: 5-24.

Schell WA (1995). New aspects of emerging fungal pathogens: a multifaceted challenge. Clin. Lab. Med., 15: 365-387.

Tamura K, Dudley J, Nei M, Kumar S (2007). MEGA4: Molecular Evolutionary Genetics Analysis (MEGA) software version 4.0. Mol. Biol. Evol., 24: 1596-1599.

Trick W, Fridkin S, Edwards J, Hajjeh R , Gaynes R (2002). Secular trend of hospital-acquired candidemia among intensive care unit patients in the United States during 1989-1999. Clin. Infect. Dis., 35: 627-630.

Wisplinghoff $\mathrm{H}$, Bischoff $\mathrm{T}$, Tallent $\mathrm{S}$, Seifert $\mathrm{H}$, Wenzel R, Edmond $\mathrm{M}$ (2004). Nosocomial bloodstream infections in US hospitals: analysis of 24,179 cases from a prospective nationwide surveillance study. Clin. Infect. Dis., 39: 309-317.

Yegres F, Richard-Yegres N, Nishimura K, Miyaji M (1991). Virulence and pathogenicity of human and environmental isolates of Cladosporium carrionii in new born ddy mice. Mycopathol., 114: 7176. 